\title{
A study on basic investigation and deterioration evaluation standard in water distribution network
}

\author{
Myeongsik Kong ${ }^{1}$, Hyundong Lee $^{2 *}$, Pilljae Kwak ${ }^{3}$ \\ ${ }^{1}$ Researcher, Department of Land, Water and Environment Research, Korea Institute of Civil Engineering and Building Technology \\ ${ }^{2}$ Senior Research Fellow, Department of Land, Water and Environment Research, Korea Institute of Civil Engineering and Building \\ Technology / University of Science and Technology \\ ${ }^{3}$ Research Fellow, Multi Disaster Countermeasures Organization, Korea Institute of Civil Engineering and Building Technology \\ *Corresponding author E-mail: hdlee@ kict.re.kr
}

\begin{abstract}
There must be a reliable evaluation to collect correct data on the factors that affect pipe performance and to analyze the acquired data to upgrade the old water distribution network effectively. This study developed a procedure for collecting the data (basic investigation) of a water distribution network and evaluating deterioration using the acquired data. The basic investigation of the water distribution network is divided into routine investigation and accident investigation. It is a process consisting of setting up investigation areas, collecting background information, and examining 23 data sets ( 9 indirect data sets, 4 endoscope data sets, and 10 shell data sets) needed to evaluate the facilities technically. We then calculated the score for each data item and the overall score for each evaluation step to evaluate structural problems, hydraulic problems, leakage through joints, and water quality problems to assess the deterioration of the investigated facility accurately.
\end{abstract}

Keywords: Water distribution network, Basic investigation, Deterioration evaluation, Indirect assessment, Endoscope.

\section{Introduction}

Water distribution networks are rehabilitated when the deterioration evaluation finds problems and judges that the facility cannot perform its intended function. The judgment on deterioration must conform to the technical evaluation method and evaluation procedure presented in the Water Distribution Network Evaluation Manual (2007, Ministry of Environment (MOE)) However, the standard presented in the Manual is inadequate for the facility manager at the local municipality or the contracted manager to apply in the field because the evaluation process and indicators are not reliable, and the evaluation indicators include information that is not readily available during maintenance work. As a result, agencies such as the Korea Water Corporation, Seoul Metropolitan Government, and Korea Environment Corporation that manage water distribution networks have conducted their own studies to develop a deterioration evaluation algorithm to supplement the Manual. However, incoherent guidelines and manuals have been difficult to use since they lacked reference data on the evaluation criteria and presented different criteria. Therefore, the need for a reliable algorithm to collect and analyze the data according to the correct procedure has been increasing. This study reviews the current status and problems with the existing guidelines for evaluating the deterioration of water distribution networks and presents a new evaluation standard that supplements the existing guidelines and can be easily applied by facilities managers in the field.

\section{Review of existing manuals for diagnosis of water distribution networks}

The MOE published the Manual for Evaluation and Management of Old Water Distribution Networks in 2002 to assess the deterioration of water distribution networks. The manual based on the procedures for evaluation deterioration in the US and Japan classified 75 deterioration evaluation factors into qualitative evaluation factors, quantitative evaluation factors, and cause analysis factors. However, it was not widely used because it did not present a reliable evaluation procedure and there were too many evaluation factors. The MOE published the Water Distribution Network Evaluation Manual in 2007 after supplementing the weaknesses, and it has been the reference for most of the standards for the performance evaluation of water distribution networks available today.

\subsection{Items of investigation and deterioration evaluation}

A total of 46 items are used for investigation and evaluation of pipe deterioration, and each item consists of 26 evaluation factors (direct and indirect), 7 general factors, and 13 corrosion factors. The weight factors applied to the direct and indirect evaluation factors can be set explicitly to the site requirements.

\subsection{Method and criteria for deterioration evaluation}

Deterioration evaluation is divided into preliminary evaluation that evaluates only indirect evaluation factors and detailed evaluation that evaluates direct and indirect evaluation factors (direct evaluation factors to be mandatory). The deterioration evaluation 
score is determined by the weighted average calculated with the weight factor set according to the specification presented above and the site condition.

Deterioration evaluation score $=\frac{\sum_{i=1}^{n} w_{i} p_{i}}{\sum_{i=1}^{n} w_{i}}$

$\mathrm{w}=$ Weight factor for each direct and indirect evaluation factor $\mathrm{p}=$ Specification for each direct and indirect evaluation factor $\mathrm{n}=$ Number of items

The Water Distribution Network Evaluation Manual recommends determining replacement or rehabilitation of pipeline based on the deterioration evaluation score. It recommends replacement or rehabilitation of the pipeline if the deterioration of indirect evaluation factors is less than 0.45 and considers the pipeline healthy if it is higher than 0.6. If it is $0.45-0.6$, it recommends excavating the pipeline for direct evaluation and considering replacement or rehabilitation depending on the advice of the site manager or expert. It recommends replacement or rehabilitation of the pipeline if the deterioration of direct evaluation factors is less than 0.55 , considers the pipeline healthy if it is higher than 0.8 , and recommends considering replacement or rehabilitation according to the condition of the pipe if it is $0.75-0.8$.

Table 1: Categories and specifications of indirect evaluation factors

\begin{tabular}{|c|c|c|c|}
\hline No. & Factor & Categorization range & Specification \\
\hline 1 & Pipe type & $\begin{array}{c}\text { CIP, GSP } \\
\text { PVC, PE } \\
\text { SP, PC, PCC } \\
\text { DCIP } \\
\text { STS, PFP }\end{array}$ & $\begin{array}{l}0.00 \\
0.25 \\
0.50 \\
0.75 \\
1.00\end{array}$ \\
\hline 2 & Pipe diameter & $\begin{array}{c}150 \mathrm{~mm} \text { or less } \\
150-350 \mathrm{~mm} \\
350-600 \mathrm{~mm} \\
600-1000 \mathrm{~mm} \\
1000-2000 \mathrm{~mm} \\
\text { More than } 2000 \mathrm{~mm}\end{array}$ & $\begin{array}{l}0.00 \\
0.20 \\
0.40 \\
0.60 \\
0.80 \\
1.00\end{array}$ \\
\hline 3 & Inner side coating & $\begin{array}{c}\text { None } \\
\text { Epoxy } \\
\text { Coal-tar enamel } \\
\text { Asphalt protective } \\
\text { coating } \\
\text { Cement mortal }\end{array}$ & $\begin{array}{l}0.00 \\
0.50 \\
0.75 \\
0.75 \\
1.00\end{array}$ \\
\hline 4 & Outerwall coating & $\begin{array}{c}\text { None } \\
\text { Coal-tar enamel } \\
\text { Asphalt protective } \\
\text { coating }\end{array}$ & $\begin{array}{l}0.00 \\
0.75 \\
1.00\end{array}$ \\
\hline 5 & Pipe age & $\begin{array}{c}\text { More than } 25 \\
20-25 \text { years } \\
15-20 \text { years } \\
10-15 \text { years } \\
\text { Less than } 10 \text { years }\end{array}$ & $\begin{array}{l}0.00 \\
0.25 \\
0.50 \\
0.75 \\
1.00\end{array}$ \\
\hline 6 & Soil type & $\begin{array}{c}\text { Clay } \\
\text { Sand+gravel and } \\
\text { loam } \\
\text { Sand+gravel and silt } \\
\text { Sand }\end{array}$ & $\begin{array}{l}0.00 \\
0.25 \\
0.50 \\
1.00\end{array}$ \\
\hline 7 & Nearby roads & $\begin{array}{l}\text { Industrial roads and } \\
\text { highways } \\
\text { Roads with more than } \\
4 \text { lanes } \\
\text { 2-Lane roads } \\
\text { Side road } \\
\text { Pedestrian road and } \\
\text { open field }\end{array}$ & $\begin{array}{l}0.00 \\
0.25 \\
0.50 \\
0.75 \\
1.00\end{array}$ \\
\hline 8 & Contact method & $\begin{array}{c}\text { Coating after welding } \\
\text { Mechanical, push-on } \\
\text { J. } \\
\text { Thermosetting } \\
\text { Flange, socket or } \\
\text { sleeve coupling }\end{array}$ & $\begin{array}{l}1.00 \\
1.00 \\
0.50 \\
0.25\end{array}$ \\
\hline 9 & $\begin{array}{l}\text { Records of leakage, rupture, } \\
\text { and valve replacement }\end{array}$ & $\begin{array}{c}\text { More than } 5 \text { times } / 5 \\
\text { years- } 50 \mathrm{~km} \\
3 \text { - } 5 \text { times } / 5 \text { years-50 }\end{array}$ & $\begin{array}{l}0.00 \\
0.25 \\
0.50\end{array}$ \\
\hline
\end{tabular}

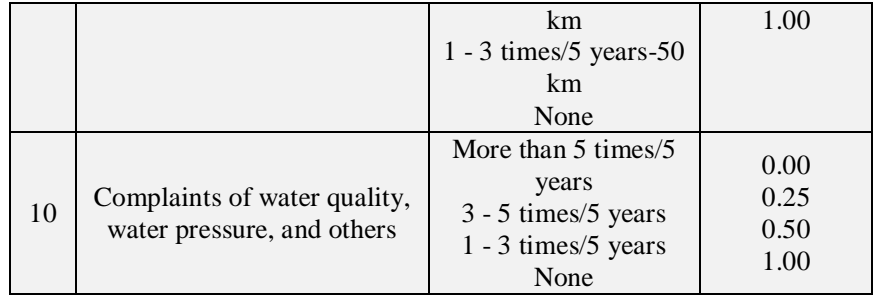

Table 2: Categories and specifications of direct evaluation factors

\begin{tabular}{|c|c|c|c|}
\hline No. & Factor & $\begin{array}{l}\text { Categorization } \\
\text { range }\end{array}$ & Specification \\
\hline 1 & Measured inner diameter & 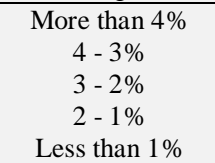 & $\begin{array}{l}0.00 \\
0.25 \\
0.50 \\
0.75 \\
1.00\end{array}$ \\
\hline 2 & Pipe thickness & $\begin{array}{c}\text { More than } 10 \% \\
10-7.5 \% \\
7.5-5 \% \\
5-2.5 \% \\
\text { Less than } 2.5 \%\end{array}$ & $\begin{array}{l}0.00 \\
0.25 \\
0.50 \\
0.75 \\
1.00\end{array}$ \\
\hline 3 & $\begin{array}{l}\text { Thickness of the protective } \\
\text { coating }\end{array}$ & $\begin{array}{c}\text { More than } 10 \% \\
10-7.5 \% \\
7.5-5 \% \\
5-2.5 \% \\
\text { Less than } 2.5 \%\end{array}$ & $\begin{array}{l}0.00 \\
0.25 \\
0.50 \\
0.75 \\
1.00\end{array}$ \\
\hline 4 & Depth of outer corrosion & $\begin{array}{c}\text { More than } 20 \% \\
20-15 \% \\
15-10 \% \\
10-5 \% \\
\text { Less than } 5 \%\end{array}$ & $\begin{array}{l}0.00 \\
0.25 \\
0.50 \\
0.75 \\
1.00\end{array}$ \\
\hline 5 & $\begin{array}{l}\text { Circumference of outer corro- } \\
\text { sion }\end{array}$ & $\begin{array}{c}\text { More than } 80 \% \\
80-60 \% \\
60-40 \% \\
40-20 \% \\
\text { Less than } 20 \%\end{array}$ & $\begin{array}{l}0.00 \\
0.25 \\
0.50 \\
0.75 \\
1.00\end{array}$ \\
\hline 6 & Peeling off of outer coating & $\begin{array}{l}\text { More than } 80 \% \\
80-60 \% \\
60-40 \% \\
40-20 \% \\
\text { Less than } 20 \%\end{array}$ & $\begin{array}{l}0.00 \\
0.25 \\
0.50 \\
0.75 \\
1.00\end{array}$ \\
\hline 7 & $\begin{array}{c}\text { Thickness of deposits inside } \\
\text { pipes }\end{array}$ & $\begin{array}{c}\text { More than } 20 \mathrm{~mm} \\
20-15 \mathrm{~mm} \\
15-10 \mathrm{~mm} \\
10-5 \mathrm{~mm} \\
\text { Less than } 5 \mathrm{~mm}\end{array}$ & $\begin{array}{l}0.00 \\
0.25 \\
0.50 \\
0.75 \\
1.00\end{array}$ \\
\hline 8 & $\begin{array}{l}\text { Depth of corrosion on inner } \\
\text { sides }\end{array}$ & $\begin{array}{c}\text { More than } 20 \mathrm{~mm} \\
20-15 \mathrm{~mm} \\
15-10 \mathrm{~mm} \\
10-5 \mathrm{~mm} \\
\text { Less than } 5 \mathrm{~mm}\end{array}$ & $\begin{array}{l}0.00 \\
0.25 \\
0.50 \\
0.75 \\
1.00\end{array}$ \\
\hline 9 & $\begin{array}{l}\text { Circumference of inner corro- } \\
\text { sion }\end{array}$ & $\begin{array}{c}\text { More than } 80 \% \\
80-60 \% \\
60-40 \% \\
40-20 \% \\
\text { Less than } 20 \%\end{array}$ & $\begin{array}{l}0.00 \\
0.25 \\
0.50 \\
0.75 \\
1.00\end{array}$ \\
\hline 10 & Peeling off of inner coating & $\begin{array}{c}\text { More than } 80 \% \\
80-60 \% \\
60-40 \% \\
40-20 \% \\
\text { Less than } 20 \%\end{array}$ & $\begin{array}{l}0.00 \\
0.25 \\
0.50 \\
0.75 \\
1.00\end{array}$ \\
\hline 11 & Thickness of maximum scale & $\begin{array}{c}\text { More than } 20 \mathrm{~mm} \\
20-15 \mathrm{~mm} \\
15-10 \mathrm{~mm} \\
10-5 \mathrm{~mm} \\
\text { Less than } 5 \mathrm{~mm}\end{array}$ & $\begin{array}{l}0.00 \\
0.25 \\
0.50 \\
0.75 \\
1.00\end{array}$ \\
\hline 12 & Water pressure & $\begin{array}{c}\text { More than } 7.0 \\
\mathrm{~kg} / \mathrm{cm} 2 \\
7.0-6.0 \mathrm{~kg} / \mathrm{cm} 2 \\
6.0-5.0 \mathrm{~kg} / \mathrm{cm} 2 \\
5.0-4.0 \mathrm{~kg} / \mathrm{cm} 2 \\
\text { Less than } 4.0 \\
\mathrm{~kg} / \mathrm{cm} 2 \\
\end{array}$ & $\begin{array}{l}0.00 \\
0.25 \\
0.50 \\
0.75 \\
1.00\end{array}$ \\
\hline
\end{tabular}




\subsection{Problems with the Manual}

The investigation and evaluation of pipeline deterioration presented in the Manual consists of 3 steps of pipe investigation and evaluation and 46 evaluation items. However, it is difficult for the facility manager to use it as is in the field because it does not specify which evaluation items (general factors, indirect evaluation factors, direct evaluation factors, and corrosion factors) to use in each evaluation step (basic, detailed, and precision).

It also does not specify the investigation method or essential data to be collected for each item and lets the municipalities determine which items to use. As such, it may be difficult to secure data for the systematic management of water distribution networks.

\section{Establishment of the procedure to assess deterioration of water distribution network}

Deterioration evaluation is carried out to investigate the internal and external conditions of the water distribution network and then perform maintenance work such as the rehabilitation and replacement according to the conditions. Deterioration evaluation requires the investigation and evaluation of direct factors such as the pipe type, age, pipe corrosion, fracture, and peeling off of coating and indirect factors such as complaints, history data, and status of nearby facilities that can affect the objective performance of the water distribution network. It also needs a series of basic investigations and evaluations to build a database. It will provide a reference to analyze the problems (structural, leakage at joints, water flow, water pressure, and water quality) of each investigated pipeline and make an accurate assessment of their state.

Figure 1. Procedure and flow of deterioration evaluation of water distribution network

\subsection{Setting of investigation area and investigation meth- od (step 1)}

In step 1, the investigation areas are separately set for the normal operations and accident investigations, and the investigation unit is configured based on the characteristics of the pipeline after collecting the basic data and pipeline data. The detailed levels of the basic investigation are selected for step 2 "Execution of the basic investigation and calculation of scores" with consideration of the collected basic data.

\subsection{Execution of the basic investigation and calculation of scores (step 2)}

The basic investigation of a water distribution network for deterioration evaluation can be mainly divided into direct investigation and indirect investigation. Indirect investigation refers to investigation in writing or by visiting that does not require a complicated procedure such as excavating underground pipes or the insertion of equipment using a valve. Indirect data is collected as evidence for inferring the overall condition of the pipes. Direct investigation refers to the process of collecting endoscope data and shell data by inserting robotic equipment such as an endoscope and collecting samples after excavation to check the pipe status more clearly by analyzing the shell directly.

The data collection process in step 2 is divided into indirect data collection, endoscope data collection, and shell data collection. After that, indirect evaluation, endoscopic evaluation, and shell evaluation are performed to calculate the score for each collected item and the overall score for each detailed level.

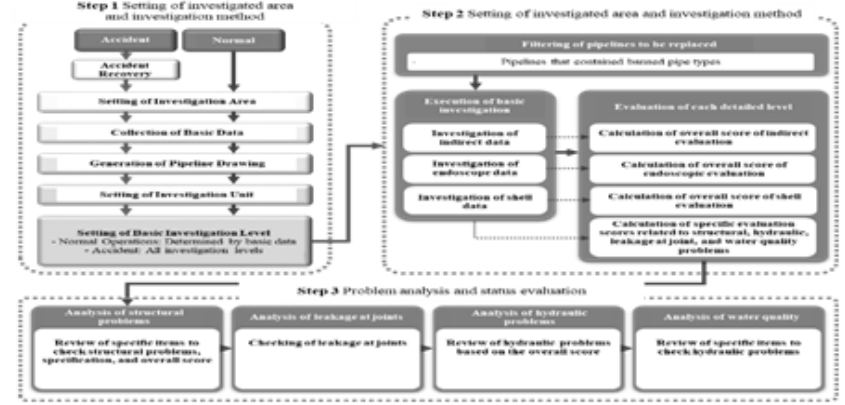

Fig. 1: Procedure and flow of deterioration evaluation of water distribution network

\subsubsection{Indirect data investigation (Level 1)}

This investigation is different from field investigation as it is the process of indirectly checking the performance of the target pipeline from the water service aspect through already available data and service engineers (operation $\&$ management). Nine investigation items are presented as the following to check the basic status such as leakage, water quality, corrosion inside pipes, water flow, water pressure, and maintenance.

Table 3: Indirect data investigation and evaluation items

\begin{tabular}{|c|c|c|c|}
\hline \multirow{2}{*}{ No } & \multicolumn{2}{|c|}{$\begin{array}{c}\text { Related } \\
\text { Problem }\end{array}$} \\
\cline { 2 - 3 } & Specification & $\begin{array}{c}\text { Weight } \\
\text { Factor }\end{array}$ & - \\
\hline 2 & $\begin{array}{c}\text { Possible leakage generation per unit of pipe } \\
\text { diameter (mm) }\end{array}$ & 0.09 & - \\
\hline 3 & Pipe installation year (year) & 0.15 & - \\
\hline 4 & $\begin{array}{c}\text { Possibility of galvanic corrosion and availa- } \\
\text { bility of preventive equipment and facilities } \\
\text { (dimensionless) }\end{array}$ & 0.09 & - \\
\hline 5 & $\begin{array}{c}\text { Road condition near the pipe installation } \\
\text { (dimensionless) }\end{array}$ & 0.06 & - \\
\hline 6 & $\begin{array}{c}\text { Pipe outer coating (dimensionless) } \\
\text { Pipe inner coating (dimensionless) }\end{array}$ & 0.10 & - \\
\hline 7 & Pinger & - \\
\hline 8 & $\begin{array}{c}\text { Number of complaints about flow rate and } \\
\text { water pressure per year(case/year/km) }\end{array}$ & 0.09 & - \\
\hline 9 & Installed pipe history data & 0.08 & - \\
\hline
\end{tabular}

\subsubsection{Endoscope data investigation (Level 2)}

This investigation has characteristics of field investigation as it is the process of inserting endoscope equipment into the pipe to collect data, directly investigating the performance (state level) of the target pipeline by visual or image inspection. Its purpose is to support decision-making concerning the improvement of the target pipeline. The investigation items to examine the pipe condition with picture or video generated by the endoscope are separated for metallic pipes and nonmetallic pipes as follows.

Table 4: Endoscope data investigation and evaluation items

\begin{tabular}{|c|c|c|c|c|c|c|}
\hline \multirow{3}{*}{$\begin{array}{c}\mathrm{N} \\
\mathrm{O}\end{array}$} & \multicolumn{5}{|c|}{ Investigation/Evaluation Item } & \multirow{3}{*}{$\begin{array}{c}\text { Related } \\
\text { Prob- } \\
\text { lem }\end{array}$} \\
\hline & \multirow{2}{*}{$\begin{array}{l}\text { Specifica- } \\
\text { tion }\end{array}$} & \multirow{2}{*}{$\begin{array}{c}\text { Measure- } \\
\text { ment }\end{array}$} & \multirow{2}{*}{$\begin{array}{l}\text { Specifica- } \\
\text { tion }\end{array}$} & \multicolumn{2}{|c|}{ Weight Factor } & \\
\hline & & & & $\begin{array}{l}\text { De- } \\
\text { tailed }\end{array}$ & $\begin{array}{l}\text { Over- } \\
\text { all }\end{array}$ & \\
\hline \multirow[t]{4}{*}{1} & \multirow{4}{*}{$\begin{array}{l}\text { Metallic } \\
\text { pipe: Dam- } \\
\text { age to lining } \\
\text { on inner } \\
\text { sides (peel- } \\
\text { ing, etc.) } \\
\text { Nonmetallic } \\
\text { pipe: Dam- } \\
\text { age to the } \\
\text { inner side } \\
\text { (deteriora- } \\
\text { tion) }\end{array}$} & \multirow{4}{*}{$\begin{array}{l}\text { Damage } \\
\text { thickness }\end{array}$} & $\mathrm{L}$ & 0.1 & \multirow[t]{4}{*}{0.8} & \multirow[t]{4}{*}{ - } \\
\hline & & & $\mathrm{M}$ & 0.3 & & \\
\hline & & & $\mathrm{H}$ & 0.5 & & \\
\hline & & & & & & \\
\hline 2 & Metallic & Degree of & $\mathrm{L}$ & 0.1 & 0.9 & Water \\
\hline
\end{tabular}




\begin{tabular}{|c|c|c|c|c|c|c|}
\hline & \multirow{2}{*}{$\begin{array}{l}\text { pipe: Corro- } \\
\text { sion inside } \\
\text { Nonmetallic } \\
\text { pipe: - }\end{array}$} & \multirow[t]{2}{*}{ corrosion } & $\mathrm{M}$ & 0.3 & & \multirow[t]{2}{*}{ quality } \\
\hline & & & $\mathrm{H}$ & 0.5 & & \\
\hline \multirow[t]{3}{*}{3} & \multirow{3}{*}{$\begin{array}{c}\text { Deposits } \\
\text { inside pipes }\end{array}$} & \multirow{3}{*}{$\begin{array}{l}\text { Thickness } \\
\text { of deposit }\end{array}$} & $\mathrm{L}$ & 0.1 & \multirow[t]{3}{*}{0.6} & \multirow{3}{*}{$\begin{array}{l}\text { Water } \\
\text { quality }\end{array}$} \\
\hline & & & $\mathrm{M}$ & 0.3 & & \\
\hline & & & $\mathrm{H}$ & 0.5 & & \\
\hline \multirow[t]{3}{*}{4} & \multirow{3}{*}{$\begin{array}{l}\text { Joint condi- } \\
\text { tion }\end{array}$} & \multirow[t]{3}{*}{ Defect level } & $\mathrm{L}$ & 0.1 & \multirow[t]{3}{*}{0.9} & \multirow{3}{*}{$\begin{array}{l}\text { Leak- } \\
\text { age at } \\
\text { joint }\end{array}$} \\
\hline & & & $\mathrm{M}$ & 0.3 & & \\
\hline & & & $\mathrm{H}$ & 0.5 & & \\
\hline
\end{tabular}

\subsubsection{Shell data investigation (Level 3)}

This investigation is the process of collecting samples and visually checking them to examine the pipe condition or to perform qualitative and quantitative analysis of physical and chemical characteristics. Its purpose is to support the final decision-making concerning the improvement of the target pipeline. Ten investigation items that can check direct factors that affect the performance of water distribution networks are presented as follows. The weight factors according to the pipe type were deduced from experts' advice and based on sample analysis data.

Table 5: Shell data investigation and evaluation items

\begin{tabular}{|c|c|c|c|c|c|c|}
\hline \multirow[t]{3}{*}{ No } & \multicolumn{5}{|c|}{ Investigation/Evaluation Item } & \multirow{3}{*}{$\begin{array}{l}\text { Related } \\
\text { Problem }\end{array}$} \\
\hline & \multirow[t]{2}{*}{ Specification } & \multicolumn{4}{|c|}{ Weight Factor } & \\
\hline & & $\begin{array}{l}\text { Steel } \\
\text { pipe }\end{array}$ & $\begin{array}{l}\text { Cast } \\
\text { iron } \\
\text { pipe }\end{array}$ & $\begin{array}{c}\text { PE } \\
\text { pipe }\end{array}$ & $\begin{array}{l}\text { PVC } \\
\text { pipe }\end{array}$ & \\
\hline 1 & $\begin{array}{l}\text { Area of peeled } \\
\text { coating on the } \\
\text { outer side } \\
\text { (area according to } \\
\text { the peel thickness) }\end{array}$ & \multicolumn{3}{|c|}{0.0324} & 0.0405 & - \\
\hline 2 & $\begin{array}{c}\text { Area of peeled } \\
\text { coating on inner } \\
\text { sides } \\
\text { (area according to } \\
\text { the peel thickness) }\end{array}$ & \multicolumn{3}{|c|}{0.0468} & 0.0585 & $\begin{array}{l}\text { Water } \\
\text { quality }\end{array}$ \\
\hline 3 & $\begin{array}{l}\text { Maximum corro- } \\
\text { sion (damage) } \\
\text { depth on the outer } \\
\text { side }\end{array}$ & \multicolumn{3}{|c|}{0.0720} & 0.0900 & Structure \\
\hline 4 & $\begin{array}{l}\text { Maximum corro- } \\
\text { sion (damage) } \\
\text { depth on inner } \\
\text { sides } \\
\end{array}$ & \multicolumn{3}{|c|}{0.0684} & 0.0855 & Structure \\
\hline 5 & $\begin{array}{l}\text { Area, according to } \\
\text { thickness, of de- } \\
\text { posits (scales) } \\
\text { inside the pipe }\end{array}$ & \multicolumn{3}{|c|}{0.0360} & 0.0450 & $\begin{array}{l}\text { Water } \\
\text { quality }\end{array}$ \\
\hline 6 & $\begin{array}{l}\text { Pipe joint condi- } \\
\text { tion (corrosion } \\
\text { (damage) })\end{array}$ & \multicolumn{3}{|c|}{0.1044} & 0.1305 & $\begin{array}{c}\text { Leakage } \\
\text { at joint }\end{array}$ \\
\hline 7 & $\begin{array}{l}\text { Shell tensile } \\
\text { strength }\end{array}$ & 0.1800 & 0.3240 & 0.4500 & 0.2640 & Structure \\
\hline 8 & $\begin{array}{l}\text { Shell yield point } \\
\text { (yield strength) }\end{array}$ & 0.1845 & 0 & 0 & 0.2860 & Structure \\
\hline 9 & Elongation rate & 0.0855 & 0.1260 & 0 & 0 & Structure \\
\hline 10 & $\begin{array}{l}\text { Chemical composi- } \\
\text { tion of the shell }\end{array}$ & \multicolumn{3}{|c|}{0.1900} & 0 & - \\
\hline
\end{tabular}

\subsubsection{Evaluation of each level}

The score of each item and the overall score for each level are calculated after indirect evaluation, endoscopic evaluation, and shell evaluation based on the results of the basic investigation. The score of each item is calculated by assigning a condition value between $0-1$ point according to predefined conditions to the item and then multiplying the weight factor set for each pipe type. The overall score is the sum of all item scores separately calculated for indirect, endoscope, and shell evaluation.

\subsection{Problem analysis and status evaluation (step 3)}

Accurate and thorough basic investigation is necessary for performing comprehensive evaluation of the structural problems, leakage in the joints, hydraulic (flow rate and water pressure) problems, and water quality problems. Step 3 can assess the problems and deterioration of facilities by considering the satisfaction of specifications, overall score, and other criteria related to structural problems, hydraulic problems, leakage at joints, and water quality problems based on the results of the indirect evaluation, endoscopic evaluation, and shell evaluation.

\subsubsection{Analysis of structural problems}

The most typical example of a structural problem in water distribution networks is a pipe rupture (circumferential rupture and traversal rupture). A pipe rupture must be fixed completely and securely since it can cause the loss of tap water, secondary damage to nearby facilities, and pollution of drinking water through penetration of pollutants. Moreover, even if the pipeline is not damaged, one can assume the presence of a structural problem if the pipe wall thickness has decreased to less than that of the specifications due to prolonged use or if the evaluation indicates that the stability of the pipeline is doubtful due to significant deterioration since these mean that a pipe rupture can occur at any time. The indirect, endoscope, and shell evaluations must be performed to calculate the item scores and overall scores to check structural problems. One can confirm the presence of a structural problem if the results of the indirect, endoscope, and shell evaluations are as follows:

- The overall score of the indirect evaluation is below 50 points.

- There are severe fractures or damage in the pipeline in the endoscope evaluation.

- The overall score of the endoscopic evaluation is below 50 points.

- The sum of the scores of the items related to structural stability is less than $50 \%$ of the full score in the shell evaluation.

- The overall score of the shell evaluation is below 50 points.

\subsubsection{Analysis of leakage at joints}

A review of the problems may indicate no structural problem even when there are leakages at joints. It is necessary to correct the visual leakage at joints even if the amount of leakage is small since this leads to economic loss in the long term and increases the risk of accident in the water distribution network which is a pressurized pipeline. The endoscope and shell evaluations can check the leakage at the joints.

- The "Defect level of joint (connected part)" is " $\mathrm{H}$ (connection defect, fracture, or total corrosion)" in the endoscope evaluation.

- The collected samples show joint leakage in the shell evaluation. - The inspection of the "Pipe joint condition (corrosion (damage) condition" shows that the area with confirmed corrosion or other damages exceeds $50 \%$ of the total joint area in the shell evaluation.

\subsubsection{Analysis of hydraulic problems}

The end users of drinking water mostly judge the service level from the water flow rate, pressure, and quality. The water flow rate and pressure indicate the hydraulic performance of the water distribution network, and the supplier must predict the demand accurately so as to install pipeline with the appropriate diameter and stably supply drinking water with proper water pressure. If the water flow rate declines because of decreased pipe diameter due to water leakage, pipe fracture, or deposits inside the pipe, the supplier must rehabilitate the pipeline to solve the problem. One can confirm the presence of a hydraulic problem through the overall scores of the indirect, endoscope, and shell evaluations. 
- The overall score of the indirect evaluation is within the specific range (50-75 points).

- The overall score of the endoscope evaluation is within the specific range (50-75 points).

- The overall score of the shell evaluation is within the specific range (50-75 points).

\subsubsection{Analysis of water quality problems}

Old pipes can cause water quality deterioration due to corrosion on the inner sides, leading to the generation of rust and a change in taste or odor. Therefore, it is critical to fix the corrosion on the inner sides through the deterioration evaluation to ensure adequate drinking water quality. The scores of the items (corrosion and deposits) that can cause water quality problems must be checked even if there are no structural, hydraulic, or water leakage problems.

- Checking "Corrosion inside pipes" shows that the area of "High" level corrosion is $50 \%$ or more of the total area or the area of "Middle" or "High" level corrosion takes up $100 \%$ of the total area in the endoscope evaluation.

- Checking "Deposits inside pipes" shows that the area of "High" level deposits is $50 \%$ or more of the total area or the area of "Middle" or "High" level deposits takes up $100 \%$ of the total area in the endoscope evaluation.

- Checking "Coating on the inner sides" shows no coating in the shell evaluation.

- Checking "Maximum depth of corrosion (damage) on the inner sides" shows $20 \%$ or more corrosion (damage) compared to the original thickness (excluding coating) in the shell evaluation.

- Checking "Area according to the thickness of deposits (scales) inside the pipe" shows that the area of deposits (scales) with a thickness of $20 \mathrm{~mm}$ or more takes up 50\% or more of the total area or the area of deposits (scales) with a thickness of $10 \mathrm{~mm}$ or more takes up $100 \%$ of the total area in the shell evaluation.

\section{Conclusion}

This study presents a standard for deterioration evaluation of a water distribution network that includes the basic investigation of the pipeline from a technical viewpoint and collecting indirect data, endoscope data, and shell data on the pipeline. Moreover, it presents an algorithm, weight factors, and specifications to convert existing pipe analysis data and data collected through experts' advice into scores for accurate determination of pipeline deterioration in the field. Lastly, it presents a method to check for hydraulic problems and water quality problems related to the water flow rate and pressure caused by various factors such as deterioration of structural stability, leakage at the joints, corrosion and deposits inside pipes, and peeling off of the coating as the water distribution network deteriorates.

The results of this study will help to deduce the proper method to solve each problem by utilizing the rehabilitation and replacement method of the old water distribution network currently developed and used.

\section{Acknowledgement}

This work is supported by the Korea PVC Pipe Industry Cooperative(KPPIC)(A Study on long-term durability and construction of PVC pipe)

\section{References}

[1] Water Distribution Network Evaluation Manual, MOE (2007)

[2] Consulting Report of the Office of Waterworks, Seoul Metropolitan Government (2015)

[3] Water Service Facility Standard, MOE (2010)
[4] Choi, J. I. (2015), A study on improvement plan of water distribution network technology inspection using statistical analysis, Master thesis, University of Science and Techlonogy (UST)

[5] Lee, H. D. (2015), Study on standardization of decision making process for the improvement of Korean water pipes, The 5th KoreaChina Water Forum

[6] Rehabilitation of Water Mains(M28), AWWA (2014)

[7] The Assess-and-Fix Approach: Using Non-Destructive Evaluations to Help Select Pipe Renewal Methods, WRF (2015) 